\title{
Analisis Faktor-Faktor Yang Mempengaruhi Cost Stickiness Pada Perusahaan Manufaktur Yang Terdaftar Di Bursa Efek Indonesia Periode 2014-2018
}

\author{
Muhammad Asrin Jazuli, Azhar Maksum, Endang Sulistya Rini \\ Magister Ilmu Akuntansi, Fakultas Ekonomi dan Bisnis, Universitas Sumatera Utara, Medan, \\ Indonesia \\ Email authors: asrinjazuli1995@gmail.com, maksumazhar5@gmail.com, \\ endangsulistyarini@yahoo.co.id
}

\begin{abstract}
ABSTRAK
Penelitian ini bertujuan untuk mengetahui dan menganalisis perilaku cost stickiness serta faktor-faktor yang mempengaruhinya seperti asset intensity, employee intensity, equity intensity, return on equity, free cash flow, leverage, dan size pada perusahaan manufaktur yang terdaftar di Bursa Efek Indonesia periode 2014-2018. Penelitian ini merupakan penelitian kuantitatif dengan penelitian bersifat asosiatif kausal dan menggunakan data sekunder berupa laporan keuangan perusahaan manufaktur yang terdaftar di Bursa Efek Indonesia periode 20142018. Populasi dalam penelitian ini adalah seluruh perusahaan manufaktur yang terdaftar di Bursa Efek Indonesia periode 2014-2018 yang berjumlah 184 perusahaan. Teknik pengambilan sampel menggunakan teknik purposive sampling dengan berdasarkan kriteria-kriteria tertentu sehingga terdapat 120 perusahaan manufaktur yang dijadikan sebagai sampel penelitian. Data dalam penelitian ini diolah dengan menggunakan software SPSS versi 22. Hasil penelitian menunjukkan bahwa terdapat perilaku cost stickiness pada kategori biaya penjualan, administrasi, dan umum perusahaan manufaktur yang terdaftar di Bursa Efek Indonesia periode 2014-2018. Selain itu, faktor asset intensity dan leverage berpengaruh positif dan signifikan terhadap cost stickiness. Employee intensity memiliki pengaruh signifikan negatif terhadap tingkat cost stickiness. Sedangkan faktor equity intensity, return on equity, free cash flow, dan size tidak berpengaruh terhadap cost stickiness.

Kata Kunci : cost stickiness, asset intensity, employee intensity, equity intensity, return on equity, free cash flow, leverage, size
\end{abstract}

\section{PENDAHULUAN}

Akuntansi tradisional mengklasifikasikan biaya menjadi dua yaitu biaya variabel (variable cost) dan biaya tetap (fixed cost). Menurut Atkinson et al. (2012), biaya variabel adalah biaya yang meningkat secara proporsional dengan perubahan tingkat aktivitas beberapa variabel, sedangkan biaya tetap adalah biaya yang tidak bervariasi dalam jangka pendek dengan aktivitas tertentu. Di lain sisi, biaya variabel memiliki hubungan yang simetris atau proporsional terhadap perubahan aktivitas dan menggambarkan pola di mana perubahan biaya tidak hanya bergantung pada besarnya perubahan aktivitas, tetapi juga pada arah perubahan (Garrison, Noreen, \& Brewer, 2010).

Perilaku biaya berdasarkan hubungannya dengan perubahan volume kegiatan yang telah dijelaskan tersebut, memiliki hubungan yang simetris dengan volume atau aktivitas sebuah perusahaan sehingga proporsionalitas dan simetri antara biaya dan aktivitas menyiratkan bahwa setiap peningkatan aktivitas sebesar $1 \%$ akan meningkatkan biaya sebesar $1 \%$, dan setiap penurunan aktivitas sebesar $1 \%$ akan menurunkan biaya sebesar $1 \%$ juga (Calleja, Steliaros, \& Thomas, 2006). Apabila dalam kenyataannya perilaku biaya tersebut tidak proporsional dan tidak simetris, maka akan menyebabkan terjadinya fenomena cost stickiness.

Menurut Anderson, Banker, \& Janakiraman (2003), cost stickiness merupakan perilaku biaya yang meningkat saat volume aktivitas meningkat dibandingkan saat volume aktivitas menurun. Sedangkan menurut Banker \& Chen (2006)cost stickiness mengacu pada fenomena bahwa biaya berkurang lebih sedikit dengan penurunan penjualan daripada peningkatan dengan peningkatan penjualan yang setara. Dengan kata lain cost stickiness merupakan perubahan biaya-biaya yang tidak seimbang dengan volume kenaikan aktivitas perusahaan. 
Berdasarkan hasil pra riset yang telah penulis lakukan sebelumnya terhadap sampel 120 perusahaan manufaktur yang terdaftar di Bursa Efek Indonesia periode 2014-2018 didapatkan hasil sebagai berikut:

Tabel 1. Pengujian Cost Stickiness Coefficients $^{\mathrm{a}}$

\begin{tabular}{|c|c|c|c|c|c|c|}
\hline \multirow[b]{2}{*}{ Model } & & \multicolumn{2}{|c|}{ Unstandardized Coefficients } & $\begin{array}{c}\text { Standardized } \\
\text { Coefficients }\end{array}$ & \multirow[b]{2}{*}{$\mathrm{t}$} & \multirow[b]{2}{*}{ Sig. } \\
\hline & & B & Std. Error & Beta & & \\
\hline 1 & (Constant) & .998 & .014 & & 72.023 & .000 \\
\hline & LN_SALES_X & .100 & .007 & .483 & 13.828 & .000 \\
\hline & DECDUM & -.088 & .018 & -.174 & -4.977 & .000 \\
\hline
\end{tabular}

\section{Sumber: Hasil OutputSoftware SPSS 22}

Seperti yang tersaji pada tabel 1.1., nilai koefisien variabel LN_SALES_X $(\beta 1)$ sebesar 0,100 dan koefisien variabel DECDUM ( $\beta 2)$ sebesar -0,088, serta masing-masing memiliki pengaruh signifikan. Berdasarkan penelitian sebelumnya dalam menentukan indikasi cost stickiness digunakan model ABJ jika nilai koefisien $\beta 1>\beta 1+\beta 2$ atau jika $\beta 1>0$ dan $\beta 2<0$. Anderson et al. (2003) mengemukakan, nilai koefisien $\beta 1$ menandakan kenaikan biaya penjualan, administrasi, dan umum ketika penjualan naik, sedangkan nilai koefisien $\beta 1+\beta 2$ menunjukkan penurunan biaya penjualan, administrasi, dan umum ketika penjualan menurun.

Oleh karena itu, berdasarkan hasil regresi pra riset yang penulis lakukan, ketika penjualan mengalami kenaikan sebesar $1 \%$, biaya penjualan, adminsitrasi, dan umum akan naik sebesar $0,100 \%$. Di sisi lain, ketika penjualan menurun sebesar $1 \%$, biaya penjualan, administrasi, dan umum akan turun sebesar 0,012\%. Hal ini menunjukkan bahwa perubahan biaya penjualan, administrasi, dan umumtidak berubah secara simetris dengan perubahan penjualan. Artinya, pada kondisi penjualan bersih menurun, besaran kenaikan kenaikan biaya penjualan, administrasi dan umum pada saat penjualan bersih naik lebih tinggi dibanding dengan besaran penurunan biaya penjualan, administrasi dan umum pada saat penjualan bersih turun. Fenomena perilaku biaya ini disebut dengan cost stickiness yang akan penulis jelaskan kembali secara lengkap pada Bab V.

Cost stickiness berhubungan dengan keputusan manajemen dalam penyesuaian sumber daya yang digunakan dalam praktik kegiatan perusahaan (Xue \& Hong, 2016). Ketika permintaan meningkat, manajer akan memutuskan untuk menambah kapasitas produksi, sehingga elemen-elemen pembentuk biaya produksi juga akan meningkat dan perusahaan juga membutuhkan tambahan modal untuk tambahan kapasitas produksi dari pihak ketiga yang akan memunculkan biaya modal. Namun ketika permintaan menurun, manajer akan meminimalkan biaya produksi dan biaya modal, tetapi tidak seluruh biaya akan turun mengikuti aktivitas perusahaan. Manajer beranggapan bahwa penurunan aktivitas terjadi tidak permanen. Manajer cenderung optimis bahwa pendapatan masa depan akan terus meningkat, sehingga manajer menunda mengurangi jumlah biaya pada periode berjalan. Sebagai contoh biaya overhead pabrik, ketika produksi turun ada kemungkinan manajer tetap memperkerjakan tenaga kerja pabrik untuk berjaga-jaga jika ada kenaikan produksi di periode mendatang, manajer juga akan tetap melakukan pemeliharaan mesin, pemeliharaan gudang dan peralatan pabrik dan manajer juga harus tetap membayar biaya modal seperti bunga atas obligasi dari pinjaman modal tersebut walaupun perusahaan sedang mengalami penurunan penjualan. Ketika manajer merasa perubahan aktivitas tersebut terjadi permanen, barulah manajer mengurangi jumlah biaya perusahaan. 
Besaran cost stickiness dalam perusahaan memiliki pengaruh terhadap pendapatan penjualan perusahaan (Weiss, 2010). Perusahaan yang memiliki tingkat cost stickiness tinggi akan menyebabkan pendapatan penjualan menurun karena aktivitasnya juga menurun dan biaya tetapnya tinggi, sehingga jika perusahaan boros maka akan terjadi inefisiensi dan laba di tahun ini atau ditahun selanjutnya tidak dapat diprediksi dengan tepat, artinya perusahaan yang memiliki cost stickiness yang tinggi akan mengalami penurunan laba yang lebih besar ketika aktivitas perusahaan atau pendapatan penjualan menurun dibandingkan dengan perusahaan yang tingkat cost stickiness nya lebih kecil, karena biaya yang memiliki cost stickiness yang tinggi dihasilkan dari penyesuaian biaya yang lebih sedikit ketika penjualan menurun, sehingga penghematan biaya lebih sedikit.

Penelitian tentang cost stickiness pernah dilakukan Subramaniam \& Weidenmier (2003) di USA, D. (Steven) He, Teruya, \& Shimizu (2010) di Jepang, Xue \& Hong (2016) di Tiongkok, Bugeja, Lu, \& Shan (2015) di Australia, Zanella, Oyelere, \& Hossain(2015) di Uni Emirat Arab, Pamplona, Fiirst, Silva, \& Zonatto (2016) di Brazil, Chile, dan Meksiko, Windyastuti (2013), Ratnawati \& Nugrahanti (2015), Evelyn (2019) di Indonesia. Secara keseluruhan, hasil penelitian tersebut menyimpulkan adanya perilaku cost stickiness pada biaya penjualan, administrasi dan umum yang berakibat pada kurangnya tingkat akurasi peramalan laba, sedangkan hasil penelitian Abu-Serdaneh (2014) di Yordania dan Nugroho \& Endarwati(2013) dan Nelmida \& Siregar (2016) di Indonesia tidak menemukan adanya perilaku cost stickiness. Pemilihan industri manufaktur dalam penelitian ini karena perusahaan pada sektor industri manufaktur memiliki tingkat cost stickiness yang lebih tinggi dibandingkan perusahaan pada sektor industri jasa dan keuangan (Subramaniam \& Weidenmier, 2003).

Anderson et al. (2003) menemukan bahwa faktor asset intensity dan employee intensity berpengaruh terhadap tingkat cost stickiness. Kedua faktor tersebut merupakan indikator biaya penyesuaian (adjustment cost) yang terjadi jika manajer menaikkan atau menurunkan committed resources perusahaan (Pichetkun, 2012). Adjustment cost telah dipelajari secara luas dalam sebagian besar penelitian empiris sebelumnya tentang perilaku biaya, seperti (Anderson et al., 2003), (Subramaniam \& Weidenmier, 2003), de Medeiros \& Costa (2005), Banker \& Chen (2006), Banker, Ciftci, \& Mashruwala (2008), Balakrishnan \& Gruca (2008), Banker, Byzalov, \& Plehn-Dujowich (2010), Pichetkun (2012), Zanella et al. (2015), dan Yunaz \& Sasongko (2018) fokus pada adjustment cost dalam kerangka kerja mereka dan menegaskan bahwa adjustment cost adalah faktor yang mengarah pada cost stickiness.

Dari hasil penelitian yang dilakukan Wahyuningtyas \& Nugrahanti (2014) yang menemukan faktor yang mempengaruhi cost stickiness hanya dengan asset intensity dengan hasil berpengaruh secara satu arah dan employee intensity dengan hasil tidak berpengaruh searah, Nugroho \& Endarwati (2013) yang mendapatkan hasil bahwa ketika asset intensity mengalami peningkatan maka cost stickiness juga akan meningkat tapi hasil sebaliknya pada employee intensity mengalami peningkatan maka cost stickiness akan mengalami penurunan. Karena terdapat hasil yang tidak sesuai dengan pengaruh elemen dari adjustment cost pada employee intensity, maka peneliti akan meneliti lebih lanjut tentang faktor-faktor dari adjustment cost theory yaitu asset intensity, employee intensity serta menambahkan faktor adjustment cost theory lain berdasarkan penelitian yang pernah dilakukan oleh Pichetkun (2012) di Thailand sebagai variabel independen yaitu equity intensity.

Faktor lain yang mempengaruhi terjadinya cost stickiness terkait dengan masalah keagenan (agency problem). Menurut Chen, Gores, \& Nasev (2013), agency problem yang menambah agency cost dinilai berdasarkan free cash flow $(F C F)$ perusahaan memiliki pengaruh terhadap tingkat cost stickiness. leverage, ROE, dan Size juga memiliki pengaruh terhadap tingkat cost stickiness seperti penelitian yang pernah dilakukan oleh Calleja et al. 
(2006), Abu-Serdaneh (2014), Warganegara \& Tamara (2014), Pichetkun (2012), dan Yunaz \& Sasongko (2018).

Melalui latar belakang tersebut penulis tertarik untuk melakukan penelitian dengan judul "Analisis Faktor-faktor yang Mempengaruhi Cost Stickiness pada Perusahaan Manufaktur yang Terdaftar di Bursa Efek Indonesia periode 2014-2018" agar dapat melihat apakah masih banyak terdapat perusahaan yang mengalami cost stickiness dan faktor-faktor apa saja yang mempengaruhinya sebagai upaya untuk menangani peristiwa tersebut.

\section{TINJAUAN PUSTAKA}

\subsection{Cost Stickiness}

Biaya dikatakan sticky apabila kenaikan biaya cenderung mudah berubah ketika penjualan meningkat dibandingkan ketika penjualan menurun. Malcom (1991) menemukan bahwa beberapa biaya memang sulit untuk disesuaikan dengan aktivitas produksinya. Biaya yang sulit untuk disesuaikan yaitu biaya tetap atau fixed cost karena biaya tersebut cenderung melekat dan sulit untuk mengikuti walaupun aktivitas perusahaan sedang menurun. Sifat biaya itulah yang menyebabkan biaya disebut cost stickiness. Biaya dapat dikatakan sticky jika besaran peningkatan biaya ketika volume aktivitas perusahaan mengalami kenaikan lebih tinggi dibandingkan ketika volume penjualan mengalami penurunan (Anderson et al., 2003) (Subramaniam \& Weidenmier, 2003) (Banker \& Chen, 2006).

\subsection{Asset Intensity}

Asset Intensity adalah rasio yang mengukur efektivitas dan efisiensi penjualan dalam pemanfaatan dan pengembangan aset, rasio ini menunjukkan banyaknya nilai dari total aset yang digunakan untuk tiap rupiah yang dihasilkan dari pendapatan penjualan. Rasio ini dapat menjelaskan seberapa sukses suatu perusahaan yang memiliki pendapatan penjualan untuk menambah kekayaan perusahaan berupa aset. Jika suatu perusahaan memiliki aset yang sesuai dengan kebutuhan produksi dari tingkat perolehan permintaan pasar maka akan menghasilkan asset intensity yang lebih tinggi. Asset intensity yang rendah menunjukkan bahwa perusahaan tidak memiliki rasa optimis atau kepercayaan akan peningkatan pendapatan penjualan di masa depan sehingga melakukan pengurangan aset saat terjadi penurunan penjualan. Rasio ini diukur dengan membandingkan antara total aset dengan penjualan bersih.

\subsection{Employee Intensity}

Employee intensity adalah rasio yang mengukur efektifitas dan efisiensi penjualan dalam pemanfaatan dan pengembangan sumberdaya manusia. Rasio ini menunjukkan penggunaan sumberdaya manusia untuk tiap rupiah yang dihasilkan dari pendapatan penjualan. Rasio ini menjelaskan perusahaan yang menghasilkan pendapatan penjualan lalu ingin memperluas pangsa pasar dengan salah satu cara menambah tenaga ahli yang memiliki kualitas yang dibutuhkan oleh perusahaan. Kebutuhan tenaga ahli akan menambah biaya yang akan dikeluarkan perusahaan, sehingga semakin tinggi employee intensity maka perusahaan akan terlihat berskala besar dan memiliki tujuan jangka panjang yang bagus karena perusahaan memiliki ramalan masa depan akan laba yang akan diperoleh. Employee intensity diukur dengan rasio jumlah karyawan terhadap penjualan bersih (Pichetkun, 2012).

\subsection{Equity Intensity}


Equity intensity adalah rasio yang menunjukkan efektivitas dari banyak uang diinvestasikan untuk menghasilkan rupiah dari pendapatan penjualan. Rasio ini menunjukkan seberapa besar perubahan penjualan setelah memperoleh dana yang ditanamkan di perusahaan. Semakin tinggi rasio ini semakin baik bagi perusahaan. Rasio ini dapat menjelaskan seberapa sukses suatu perusahaan dalam memanfaatkan modalnya untuk menghasilkan laba. Jika suatu perusahaan akan melakukan pemanfaatan modal secara optimal maka akan menghasilkan equity intensity yang lebih tinggi. Equity intensity diukur dengan membandingkan total ekuitas dengan total penjualan bersih.

\subsection{Return On Equity (ROE)}

Profitabilitas merupakan kemampuan suatu perusahaan dalam menghasilkan laba selama periode tertentu (Sitompul, 2020). Rasio profitabilitas digunakan untuk mengetahui kemampuan sebuah perusahaan dalam menghasilkan laba selama periode tertentu dan juga gambaran tentang tingkat efektivitas manajemen dalam melaksanakan kegiatan operasinya dalam periode yang sama. Return on Equity (ROE) digunakan sebagai proksi untuk mengukur profitabilitas sesuai dengan penelitian yang dilakukan (Calleja et al., 2006), (I Kama \& Weiss, 2010), (Yunaz \& Sasongko, 2018) dan (Evelyn, 2019).

\subsection{Free Cash Flow (FCF)}

Free cash flow merupakan arus kas yang tersedia untuk didistribusikan kepada seluruh investor (pemegang saham dan pemilik utang) setelah perusahaan menempatkan seluruh investasinya pada aset tetap dan modal kerja yang dibutuhkan untuk mempertahankan operasi yang sedang berjalan (Brigham \& Houston, 2006). Free cash flow menggambarkan kepada investor bahwa dividen yang dibagikan oleh perusahaan bukan hanya sebagai strategi menyiasati pasar dengan maksud meningkatkan nilai perusahaan. Bagi perusahaan yang mengeluarkan pengeluaran modal, free cash flow akan mencerminkan dengan jelas mengenai perusahaan manakah yang masih mempunyai kemampuan di masa depan atau tidak. Pasar akan bereaksi jika terlihat ada free cash flow yang dapat meningkatkan harapan mereka untuk mendapatkan dividen di masa depan sesuai dengan penelitian yang dilakukan Pichetkun (2012), Abu-Serdaneh (2014), dan Yunaz \& Sasongko (2018).

\subsection{Leverage}

Leverage adalah salah satu rasio keuangan yang merupakan hubungan antara utang perusahaan terhadap modal maupun aset perusahaan. Leverage merupakan alat ukur untuk melihat ketergantungan perusahaan kepada kreditor dalam membiayai aset perusahaannya (Maulinda, 2019). Leverage membandingkan dana yang diinvestasikan pemilik dengan dana yang disediakan kreditur, atau perbandingan antara modal dan utang perusahaan (Situmeang, 2014). Kreditur memperhatikan rasio ini karena merupakan ukuran keamanan dari uang yang mereka pinjamkan kedalam suatu perusahaan. Semakin besar porsi dana yang dimiliki oleh pemilik maka dana kreditur relatif lebih aman. Dalam terminologi yang lain leverage dikatakan sebagai ukuran seberapa jauh aset dibiayai oleh utang. Dalam penelitian ini leverage doproksikan kedalam debt to equity ratio (DER). DER merupakan perbandingan antara total utang dengan ekuitas dalam pendanaan perusahaan. Rasio ini juga menunjukan kemampuan modal sendiri perusahaan untuk memenuhi seluruh kewajibannya sesuai dengan penelitian yang dilakukan Pichetkun (2012), Warganegara \& Tamara (2014), Yunaz \& Sasongko (2018), dan Evelyn (2019).

\subsection{Size}


Dalam mengelola perusahaan, ukuran perusahaan merupakan salah satu variabel yang penting. Menurut Brigham \& Houston (2006) ukuran perusahaan adalah skala besar kecilnya perusahaan yang dapat diklasifikasikan berdasarkan berbagai cara antara lain dengan ukuran pendapatan, total aset, dan total ekuitas. Dilihat dari ukurannya, perusahaan dibagi menjadi tiga, yaitu perusahaan besar, menengah, dan kecil, dimana perusahaan yang besar memiliki sistem manajemen yang lebih kompleks dan memiliki laba yang lebih tinggi (Evelyn, 2019). Log total aset digunakan untuk mengukur ukuran perusahaan agar mendapatkan ukuran yang stabil dan distribusi yang relatif normal (Yosvid, 2020). Oleh sebab itu, perusahaan yang besar memiliki risiko serta masalah yang lebih kompleks serta akan dikenakan biaya politis yang lebih tinggi daripada perusahaan perusahaan kecil dan menengah. Para peneliti telah menggunakan ukuran perusahaan sebagai proksi untuk sensitivitas politik perusahaan dan sebagai insentif bagi manajemen untuk meningkatkan pendapatan. Semakin besar suatu perusahaan, semakin besar kemungkinan terjadinya transfer kekayaan, jika dibandingkan dengan perusahaan kecil ((Seay, Pitts, \& Kamery, 2004), (Warganegara \& Tamara, 2014), (Pichetkun, 2012), dan (Evelyn, 2019)).

\section{KERANGKA KONSEPTUAL DAN HIPOTESIS PENELITIAN}

\subsection{Kerangka Konseptual}

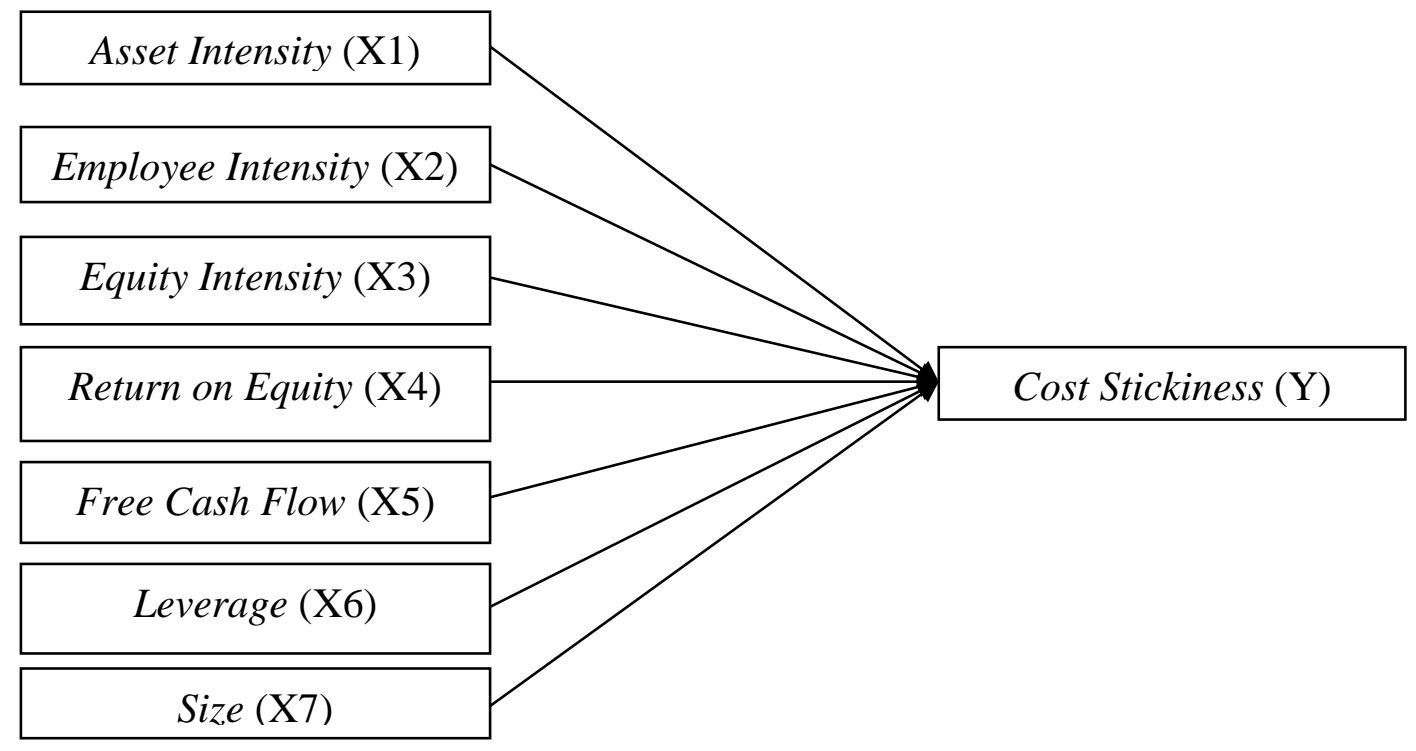

Gambar 1. Kerangka Konseptual

\subsection{Hipotesis Penelitian}

H1 : Asset intensity berpengaruh positif terhadap cost stickiness

$\mathrm{H} 2$ : Employee intensity berpengaruh positif terhadap cost stickiness

H3 : Equity intensity berpengaruh positif terhadap cost stickiness

H4 : Return on Equity berpengaruh negatif terhadap cost stickiness

H5 : Free Cash Flow berpengaruh positif terhadap cost stickiness

H6 : Leverage berpengaruh negatif terhadap tingkat cost stickiness

H7 : Size berpengaruh positif terhadap cost stickiness 


\section{METODE PENELITIAN}

Jenis penelitian yang digunakan dalam penelitian ini adalah kausal yang bertujuan untuk menganalisis bagaimana suatu variabel mempengaruhi variabel lain. Penelitian ini adalah untuk menganalisis pengaruh asset intensity, employee intensity, equity intensity, return on equity, free cash flow, leverage, dan size terhadap cost stickiness. Penelitian ini dilakukan pada perusahaan manufaktur yang terdaftar di Bursa Efek Indonesia (BEI) periode tahun 2014 sampai dengan tahun 2018 yang diperoleh dari situs www.idx.co.id dan Kantor Perwakilan Bursa Efek Indonesia Cabang Medan.

Peneliti menggunakan teknik purposive sampling dalam menentukan sampel penelitiannya yang dimana penentuannya berdasarkan atas kriteria-kriteria tertentu sebagai berikut :

1) Perusahaan-perusahaan yang termasuk dalam industri manufaktur yang terdaftar di BEI dan mempublikasikan laporan keuangan secara lengkap dan konsisten yang telah diaudit per tanggal 31 Desember dari tahun 2014-2018.

2) Perusahaan yang dipilih sebagai sampel memiliki kelengkapan data laporan keuangan yang digunakan sebagai variabel dalam penelitian ini, selama periode penelitian yaitu tahun 2014-2018.

3) Biaya penjualan, administrasi dan umum tidak melebihi penjualan bersih.

Penelitian ini menggunakan model regresi linear berganda. Terdapat dua model persamaan yang digunakan dalam penelitian ini. Persamaan model ABJ (Anderson, Banker, Janakiraman) diperkenalkan oleh Anderson, banker \& Janakiraman pada tahun 2003 untuk menemukan indikasi adanya cost stickiness, berikut persamaan 1 pengujian cost stickiness yang digunakan dalam penelitian ini:

$$
\log \left[\frac{S G \& A_{i t}}{S G \& A_{i, \mathbb{N}}}\right]=\beta_{0}+\beta_{1} \log \left[\frac{\text { Sales }_{i t}}{\text { Sales }_{i, 1}}\right]+\beta_{2} * \text { DecDummy }_{i t} * \log \left[\frac{\text { Sales }_{i t}}{\text { Sales }_{i, \mathrm{~N}}}\right]+\varepsilon_{i, t}
$$

Biaya penjualan, administrasi, dan umum terindikasi cost stickiness apabila $\beta 1$ lebih besar dari $\beta 1+\beta 2$ :

$$
\begin{aligned}
& \mathrm{H} 1_{0} \quad \text { : } \quad \beta 1=\beta 2=0 \\
& \mathrm{H} 1_{\mathrm{a}} \quad \text { : } \beta 1>\beta 1+\beta 2 \text { atau } \beta 2<0
\end{aligned}
$$

Sedangkan persamaan yang kedua terkait dengan faktor-faktor yang mempengaruhi tingkat cost stickiness disebut sebagai persamaan 2 adalah sebagai berikut :
LnSGA $_{\text {it }}$
$=\beta 0+\beta 1$ LnSALES $_{\text {it }}+\beta 2$ DECDUM $_{\mathrm{it}}{ }^{*}$ LnSALES $_{\mathrm{it}}+$
$\beta_{3 D^{2} C D U M}{ }_{i t}^{*} \operatorname{LnSALES}_{\mathrm{it}}{ }^{*}$ ASSET $_{\mathrm{it}}+$
$\beta 4$ DECDUM $_{\mathrm{it}}{ }^{*}$ LnSALES $^{*}$ EMPLOYEE $_{\mathrm{it}}+$
$\beta 5$ DECDUM $_{\text {it }} *$ LnSALES $_{i t} *$ EQUITY $_{\text {it }}$
$\beta 6$ DECDUM $_{\mathrm{it}}{ }^{*} \operatorname{LnSALES}_{\mathrm{it}} * \mathrm{ROE}_{\mathrm{it}}+$
$\beta$ 7DECDUM ${ }_{\mathrm{it}} *$ LnSALES $_{\mathrm{it}} *$ FCFit +
$\beta 8$ DECDUM $_{\mathrm{it}} * \operatorname{LnSALES}_{\mathrm{it}}{ }^{*} \mathrm{DER}_{\mathrm{it}}+$
$\beta 9 D E C D U M_{i t} * \operatorname{LnSALES}_{\mathrm{it}} * \mathrm{SIZE}_{\mathrm{it}}+\varepsilon \mathrm{it}$ 
Berikut adalah kriteria pengujian hipotesis regresi model ABJ :

a. Jika taraf signifikan $>0.05 \mathrm{H}_{0}$ ditolak

b. Jika taraf signifikan $<0.05 \mathrm{H}_{0}$ diterima

\section{TEMUAN DAN PEMBAHASAN}

\subsection{Hasil}

\section{Penetapan Sampel Penelitian}

Populasi dalam penelitian ini adalah seluruh perusahaan manufaktur yang terdaftar di Bursa Efek Indonesia (BEI) sebanyak 184 perusahaan. Berdasarkan kriteria pemilihan sampel pada bab sebelumnya, tidak semua perusahaan manufaktur yang terdaftar di BEI periode 2014-2018 memenuhi kriteria dalam penelitian ini. Berikut merupakan tabel penentuan sampel berdasarkan kriteria yang telah ditentukan sebelumnya :

Tabel 2. Penentuan Sampel

\begin{tabular}{lc}
\hline \multicolumn{1}{c}{ Kriteria } & Jumlah Perusahaan \\
\hline Jumlah Populasi & 184 \\
\hline $\begin{array}{l}\text { Perusahaan manufaktur yang tidak terdaftar dari tahun } \\
2014 \text { atau sebelum tahun 2014 dan menghentikan } \\
\text { operasinya sebelum 2018 }\end{array}$ & $(48)$ \\
\hline $\begin{array}{l}\text { Perusahaan manufaktur yang tidak memiliki } \\
\text { kelengkapan data laporan keuangan yang digunakan } \\
\text { sebagai variabel dalam penelitian ini, selama periode } \\
\text { penelitian yaitu tahun2014-2018 }\end{array}$ & $(16)$ \\
\hline $\begin{array}{l}\text { Perusahaan manufaktur yang biaya penjualan, } \\
\text { administrasi dan umum melebihi penjualan bersih }\end{array}$ & 0 \\
\hline Jumlah sampel yang terseleksi & 120 \\
\hline
\end{tabular}

Sumber: Hasil Olahan Peneliti

\section{Analisis Koefisien Determinasi (R2)}

Koefisien determinasi $\left(R^{2}\right)$ merupakan suatu nilai (nilai proporsi) yang mengukur seberapa besar kemampuan variabel-variabel independen yang digunakan dalam persamaan regresi, dalam menerangkan variasi variabel dependen. Dalam hal ini adjusted $\mathrm{R}^{2}$ digunakan untuk mengetahui seberapa besar pengaruh variabel asset intensity, employee intensity, equity intensity, Return on Equity, Free Cash Flow, Leverage, dan Size. 
Tabel 3. Koefisien Determinasi Model Summary ${ }^{b}$

\begin{tabular}{llcccr}
\hline Model & $\mathrm{R}$ & R Square & $\begin{array}{c}\text { Adjusted R } \\
\text { Square }\end{array}$ & $\begin{array}{l}\text { Std. Error of } \\
\text { the Estimate }\end{array}$ & $\begin{array}{c}\text { Durbin- } \\
\text { Watson }\end{array}$ \\
\hline 1 & $.475^{\mathrm{a}}$ & .226 & .216 & .12212244 & 2.095 \\
\hline
\end{tabular}

a. Predictors: (Constant), Size (X7), Asset Intensity (X1), ROE (X4), Leverage (X6), FCF (X5), Employee Intensity (X2), Equity Intensity (X3)

b. Dependent Variable: Cost Stickiness (Y)

\section{Sumber : Hasil Output Software SPSS 22}

Berdasarkan Tabel 3., diketahui nilai koefisien determinasi (Adjusted R-Square) adalah 0.216. Nilai tersebut dapat diartikan variabel asset intensity, employee intensity, equity intensity, ROE, $\mathrm{FCF}$, leverage, dan size secara bersama-sama atau simultan mampu mempengaruhi cost stickiness sebesar $21,6 \%$, sisanya sebesar 78,4\% dijelaskan oleh variabel atau faktor lain yang tidak diukur atau diteliti dalam penelitian ini. Standard Error of Estimates (SEE) sebesar 0,12212244. Semakin kecil nilai SEE akan membuat model regresi semakin tepat dalam memprediksi variabel dependen (Ghozali, 2012).

\section{Uji F ( Uji Signifikansi Simultan)}

Uji statistik F dilakukan untuk melihat apakah secara bersama-sama atau secara simultan variabel independen berpengaruh terhadap variabel dependen.

Tabel 4. Uji Pengaruh Simultan dengan Uji $F$

\begin{tabular}{llrrrrr}
\multicolumn{7}{c}{ ANOVA $^{\mathbf{b}}$} \\
\hline \multirow{2}{*}{ Model } & & \multicolumn{5}{c}{ Mean } \\
\hline 1 & Regression & Sum of Squares & Df & Square & F & Sig. \\
\hline & Residual & 2.465 & 7 & .352 & 23.613 & $.000^{\mathbf{a}}$ \\
& Total & 8.456 & 567 & .015 & & \\
& & 10.921 & 574 & & & \\
\hline
\end{tabular}

a. Predictors: (Constant), Size (X7), Asset Intensity (X1), ROE (X4),

Leverage (X6), FCF (X5), Employee Intensity (X2), Equity Intensity (X3)

b. Dependent Variable: Cost Stickiness (Y)

Sumber : Hasil Output Software SPSS 22

Berdasarkan Tabel 4., diketahui nilai F hitung 23,613 dan nilai Sig. adalah 0,000. nilai Sig. $0,000<0,05$, maka asset intensity, employee intensity, equity intensity, ROE, FCF, leverage, size secara simultan atau bersama-sama berpengaruh signifikan terhadap cost stickiness.

\section{Uji t (Uji Signifikansi Pengaruh Parsial)}

Uji parsial (Uji t) digunakan untuk menguji sampai sejauh mana suatu variabel independen berpengaruh terhadap variabel dependennya. Berikut tabel 5. menyajikan nilai koefisien regresi, serta nilai statistik t untuk pengujian pengaruh secara parsial : 
Tabel 5. Uji Signifikansi Pengaruh Parsial (Uji $t$ )

\begin{tabular}{lcccccc}
\hline & \multicolumn{2}{c}{$\begin{array}{c}\text { Unstandardized } \\
\text { Coefficients }\end{array}$} & \multicolumn{2}{c}{$\begin{array}{c}\text { Standardized } \\
\text { Coefficients }\end{array}$} & & \\
\cline { 2 - 5 } Model & B & Std. Error & Beta & t & Sig. \\
\hline $1 \quad$ (Constant) & .114 & .104 & & & 1.098 & .273 \\
Asset Intensity & .126 & .020 & .292 & 6.440 & .000 \\
(X1) & & & & & \\
Employee & -.020 & .004 & -.214 & -4.939 & .000 \\
Intensity (X2) & & & & & \\
Equity & -.021 & .012 & -.106 & -1.792 & .074 \\
Intensity (X3) & & & & & \\
ROE (X4) & .005 & .005 & .042 & 1.010 & .313 \\
FCF (X5) & .013 & .009 & .084 & 1.478 & .140 \\
Leverage (X6) & .010 & .004 & .100 & 2.482 & .013 \\
Size (X7) & .001 & .004 & .012 & .297 & .766 \\
\hline
\end{tabular}

Sumber : Hasil Output Software SPSS 22

Berdasarkan Tabel 5.10., diperoleh persamaan regresi linear berganda sebagai berikut :

$$
\begin{gathered}
Y=0,114+0,126 X_{1}-0,020 X_{2}-0,021 X_{3}+0,005 X_{4}+0,013 X_{5}+0,010 X_{6}+0,001 X_{7} \\
+e
\end{gathered}
$$

Diketahui:

1. Diketahui nilai koefisien regresi dari variabel asset intensity bernilai positif, yakni 0.126 .

Hal ini berarti variabel asset intensity berpengaruh positif terhadap cost stickiness.

Diketahui nilai t hitung dari variabel asset intensity adalah 6.440 dan nilai Sig. dari variabel asset intensity adalah $0.000<0,05$, maka disimpulkan asset intensity berpengaruh positif dan signifikan terhadap cost stickiness.

2. Diketahui nilai koefisien regresi dari variabel employee intensity bernilai negatif, yakni 0.020. Hal ini berarti variabel employee intensity berpengaruh negatif terhadap cost stickiness. Diketahui nilai thitung dari variabel employee intensity adalah -4.939 dan nilai Sig. dari variabel employee intensity adalah $0.000<0,05$, maka disimpulkan employee intensity berpengaruh negatif dan signifikan terhadap cost stickiness.

3. Diketahui nilai koefisien regresi dari variabel equity intensity bernilai negatif, yakni 0.021. Hal ini berarti variabel equity intensity berpengaruh negatif terhadap cost stickiness. Diketahui nilai t hitung dari variabel equity intensity adalah -1.792 dan nilai Sig. dari variabel equity intensity adalah $0.074>0,05$, maka disimpulkan equity intensitytidak berpengaruh terhadap cost stickiness.

4. Diketahui nilai koefisien regresi dari variabel ROE bernilai positif, yakni 0.005. Hal ini berarti variabel ROE berpengaruh positif terhadap cost stickiness. Diketahui nilai t hitung dari variabel ROE adalah 1.010 dan nilai Sig. dari variabel ROE adalah $0.313>0,05$, maka disimpulkan ROE tidak berpengaruh terhadap cost stickiness.

5. Diketahui nilai koefisien regresi dari variabel FCF bernilai positif, yakni 0.013. Hal ini berarti variabel FCF berpengaruh positif terhadap cost stickiness. Diketahui nilai t hitung dari variabel FCF adalah 1.478 dan nilai Sig. dari variabel FCF adalah $0.140>0,05$, maka disimpulkan FCF tidak berpengaruh terhadap cost stickiness. 
6. Diketahui nilai koefisien regresi dari variabel leverage bernilai positif, yakni 0.010 . Hal ini berarti variabel leverage berpengaruh positif terhadap cost stickiness. Diketahui nilai t hitung dari variabel leverage adalah 2.482 dan nilai Sig. dari variabel leverage adalah $0.013<0,05$, maka disimpulkan leverage berpengaruh positif dan signifikan terhadap cost stickiness.

7. Diketahui nilai koefisien regresi dari variabel size bernilai positif, yakni 0.001 . Hal ini berarti variabel size berpengaruh positif terhadap cost stickiness. Diketahui nilai t hitung dari variabel size adalah 0.297 dan nilai Sig. dari variabel size adalah $0.766>0,05$, maka disimpulkan sizetidak berpengaruh terhadap cost stickiness.

\section{Pengujian Model ABJ}

Tabel 6.Pengujian Cost Stickiness Coefficients $^{\text {a }}$

\begin{tabular}{|c|c|c|c|c|c|c|}
\hline \multirow[b]{2}{*}{ Model } & & \multicolumn{2}{|c|}{$\begin{array}{c}\text { Unstandardized } \\
\text { Coefficients }\end{array}$} & $\begin{array}{l}\text { Standardized } \\
\text { Coefficients } \\
\end{array}$ & \multirow[b]{2}{*}{$\mathrm{t}$} & \multirow[b]{2}{*}{ Sig. } \\
\hline & & B & $\begin{array}{l}\text { Std. } \\
\text { Error }\end{array}$ & Beta & & \\
\hline \multirow[t]{3}{*}{1} & (Constant) & .998 & .014 & & 72.023 & .000 \\
\hline & LN_SALES_X & .100 & .007 & .483 & 13.828 & .000 \\
\hline & DECDUM & -.088 & .018 & -.174 & -4.977 & .000 \\
\hline
\end{tabular}

a. Dependent Variable: LN_SGA_Y

Sumber : Hasil Output Software SPSS 22

Berdasarkan Tabel 6., diperoleh $\beta_{0}=0,998, \beta_{1}=0,100$ dan $\beta_{2}=-0,088$. Diketahui:

$$
\begin{gathered}
\beta_{1}>\beta_{1}+\beta_{2} \\
0,100>(0,100)+(-0,088) \\
0,100>0,012
\end{gathered}
$$

dan juga $\beta_{2}<0$, yakni $-0,088<0$, maka disimpulkan terjadi cost stickiness.

Berdasarkan hasil pengujian cost stickiness pada tabel 10. dapat diinterpretasikan bahwa ketika penjualan mengalami kenaikan sebesar $1 \%$, beban penjualan, umum, dan administrasi akan naik sebesar $0,100 \%$. Di sisi lain, ketika penjualan menurun sebesar $1 \%$, beban penjualan, umum, dan administrasi akan turun sebesar $0,012 \%$. Hal ini menunjukkan bahwa perubahan beban penjualan, umum, dan administrasi tidak berubah secara simetris dengan perubahan penjualan. Artinya, pada kondisi penjualan bersih menurun, besaran kenaikan kenaikan beban penjualan, umum, dan administrasi pada saat penjualan bersih naik lebih tinggi dibanding dengan besaran penurunan biaya penjualan, umum, dan administrasi pada saat penjualan bersih turun. Hasil penelitian ini sesuai dengan hasil penelitian Anderson et al. (2003), Subramaniam \& Weidenmier (2003) di USA, D. (Steven) He, Teruya, \& Shimizu, (2010) di Jepang, Xue \& Hong (2016) di Tiongkok, Bugeja, Lu, \& Shan (2015) di Australia, Zanella, Oyelere, \& Hossain (2015) di Uni Emirat Arab, Pamplona, Fiirst, Silva, \& Zonatto (2016) di Brazil, Chile, dan Meksiko, Windyastuti (2013), Ratnawati \& Nugrahanti (2015), Evelyn (2019) di Indonesia. 


\subsection{Pembahasan}

\section{Pengaruh Asset Intensity Terhadap Cost Stickiness}

Variabel asset intensity memiliki nilai koefisien regresi bernilai positif, yakni 0.126 . Hal ini berarti variabel asset intensity berpengaruh positif terhadap cost stickiness. Diketahui nilai t hitung dari variabel asset intensity adalah 6.440 dan nilai Sig. dari variabel asset intensity adalah $0.000<0,05$. Hal ini berarti $\mathrm{H} 1$ diterima yakni asset intensity berpengaruh positif dan signifikan terhadap cost stickiness. Hal ini menunjukkan bahwa ketika asset intensity meningkat sebesar 1 satuan, maka cost stickiness akan meningkat sebesar 0.126. Hasil penelitian ini sesuai dengan hasil penelitian Anderson et al. (2003), Calleja et al. (2006), Chen et al.(2012), Wahyuningtyas \& Nugrahanti (2014), Yunaz \& Sasongko (2018), dan Evelyn (2019).

Keputusan manajemen untuk melakukan penyesuaian pada aset ketika mengalami penurunan penjualan sangat beresiko tinggi karena perusahaan akan kehilangan investasi yang spesifik (Anderson et al., 2003). Perusahaan yang menggunakan aset untuk melakukan kegiatan operasionalnya akan mengalami cost stickiness yang lebih tinggi. Hal ini yang menyebabkan timbulnya adjustment cost (biaya mengurangi jumlah aset) dan holding cost (biaya mempertahankan aset). Menurut adjustment cost theory yang berhubungan dengan hipotesis ini, akan mudah menurunkan skala pembelian aset saat penjualan menurun, tetapi membuang aset perusahaan yang tidak digunakan akan lebih mahal karena perusahaan harus membayar biaya penjualan aset. Kecenderungan manajer yang akan mempertahankan aset saat penjualan menurun akan menyebabkan biaya penjualan, umum, dan administrasi akan menjadi lebih besar karena perusahaan tetap mengeluarkan biaya pemeliharaan atas aset perusahaan. Hal ini akan berdampak pada penurunan laba perusahaan.

\section{Pengaruh Employee Intensity Terhadap Cost Stickiness}

Variabel employee intensity memiliki nilai koefisien regresi bernilai negatif, yakni -0.020 . Hal ini berarti variabel employee intensity berpengaruh negatif terhadap cost stickiness. Diketahui nilai thitung dari variabel employee intensity adalah -4.939 dan nilai Sig. dari variabel employee intensity adalah $0.000<0,05$, maka disimpulkan employee intensity berpengaruh negatif dan signifikan terhadap cost stickiness. Hal ini berarti $\mathrm{H} 2$ ditolak yakni employee intensity tidak memiliki pengaruh positif dan signifikan terhadap cost stickiness. Hal ini menunjukkan bahwa ketika employee intensity meningkat sebesar 1 satuan, maka cost stickiness akan menurun sebesar -0.020. Hasil penelitian ini sesuai dengan hasil penelitian Chen et al. (2012), Brüggen \& Zehnder (2014), dan Bugeja et al. (2015).

Employee intensity yang berpengaruh negatif dalam penelitian ini diduga karena adanya karyawan Perjanjian Kerja Waktu Tertentu (PKWT) yang banyak daripada karyawan tetap itu sendiri. Di Indonesia, regulasi mengenai karyawan PKWT diatur dalam Undang-undang No. 13 Tahun 2003 tentang ketenagakerjaan. Biaya yang timbul dari menambah atau mengurangi karyawan PKWT lebih rendah daripada karyawan tetap. Karyawan PKWT dapat diperpanjang atau diberhentikan dengan tetap memberikan hak nya tetapi tidak sebesar karyawan tetap. Hal ini sejalan dengan alasan Chen et al. (2012) bahwa adjustment cost yang dikeluarkan perusahaan akan lebih kecil sehingga tingkat cost stickiness tidak terpengaruh oleh employee intensity.

\section{Pengaruh Equity Intensity Terhadap Cost Stickiness}

Variabel equity intensity memiliki nilai koefisien regresi bernilai negatif, yakni -0.021. Hal ini berarti variabel equity intensity berpengaruh negatif terhadap cost stickiness. Diketahui nilai $\mathrm{t}$ hitung dari variabel equity intensity adalah -1.792 dan nilai Sig. dari variabel equity intensity adalah $0.074>0,05$, maka disimpulkan equity intensity berpengaruh negatif terhadap cost 
stickiness, namun tidak signifikan. Hal ini berarti H3 ditolak yakni equity intensity tidak berpengaruh terhadap cost stickiness. Hasil penelitian ini sesuai dengan hasil penelitian Eltivia, Ekasari, Wahyuni, \& Isrowiyah (2019) yang menemukan adanya pengaruh negatif equity intensity terhadap cost stickiness. Namun hasil penelitian ini bertolak belakang dengan penelitian Pichetkun (2012) yang menemukan adanya pengaruh equity intensity dengan tingkat cost stickiness.

Equity intensity yang berpengaruh negatif dalam penelitian ini diduga karena adanya kelonggaran dalam pembayaran angsuran kredit dalam jangka waktu tertentu jika kondisi perusahaan sedang mengalami penurunan penjualan. Di Indonesia, regulasi mengenai penundaan pembayaran angsuran kredit diatur dalam Undang-undang No. 37 Tahun 2004 tentang Kepailitan dan Penundaan Kewajiban Pembayaran Utang. Dalam menjalankan kegiatan usahanya perusahaan mendapatkan pinjaman modal dari pihak ketiga dan pelunasannya dilakukan setiap bulan atau sesuai dengan kontrak perjanjian ditambah dengan biaya bunga. Apabila dalam perjalanannya perusahaan mengalami kesulitan dan penjualan yang menurun maka perusahaan dapat mengajukan permohonan penundaan kewajiban pembayaran utang kepada kreditor dalam jangka waktu tertentu hingga perusahaan kembali pulih seperti sedia kala dan melanjutkan pembayaran angsuran nya kembali.

\section{Pengaruh Return on Equity (ROE) Terhadap Cost Stickiness}

Variabel ROE memiliki nilai koefisien regresi bernilai positif, yakni 0.005 . Hal ini berarti variabel ROE berpengaruh positif terhadap cost stickiness. Diketahui nilai t hitung dari variabel ROE adalah 1.010 dan nilai Sig. dari variabel ROE adalah $0.313>0,05$, maka disimpulkan ROE berpengaruh positif terhadap cost stickiness, namun tidak signifikan. Hal ini berarti H4 ditolak yakni Return on Equity (ROE) tidak berpengaruh terhadap cost stickiness. Hasil penelitian ini sesuai dengan hasil penelitian Calleja et al. (2006) dan Evelyn (2019).

Return on Equity (ROE) tidak mempunyai pengaruh yang signifikan terhadap cost stickiness ini secara tidak langsung dikarenakan perilaku manajemen yang tidak mengambil keputusan apapun ketika perusahaan mengalami penurunan penjualan sehingga keputusan manajemen yang berdampak pada cost stickiness tidak diambil. Hal ini mungkin juga karena manajemen masih mementingkan keuntungan pribadinya dibandingkan dengan penciptaan nilai untuk para pemegang saham karena manajemen tidak mendapatkan insentif atas pencapaian target laba yang akan diraihnya.

\section{Pengaruh Free Cash Flow (FCF) Terhadap Cost Stickiness}

Variabel FCF memiliki nilai koefisien regresi bernilai positif, yakni 0.013. Hal ini berarti variabel FCF berpengaruh positif terhadap cost stickiness. Diketahui nilai t hitung dari variabel FCF adalah 1.478 dan nilai Sig. dari variabel FCF adalah $0.140>0,05$, maka disimpulkan FCF berpengaruh positif terhadap cost stickiness, namun tidak signifikan. Hal ini berarti H5 ditolak yakni free cash flow (FCF) tidak berpengaruh terhadap cost stickiness. Hasil penelitian ini sesuai dengan hasil penelitian Brüggen \& Zehnder (2014) dan Yunaz \& Sasongko (2018) yang tidak menemukan adanya signifikansi pengaruh free cash flow (FCF) terhadap cost stickiness.

Free cash flow (FCF) yang tidak berpengaruh signifikan terhadap cost stickiness dapat disebabkan oleh berbagai faktor. Pertama, perusahaan diduga masih menggunakan FCF untuk melakukan investasi kembali dalam rangka untuk meningkatkan nilai perusahaan daripada untuk kepentingan pribadi manajemen dan tidak mempengaruhi manajemen dalam pengambilan keputusan. Kedua, karakteristik perusahaan yang terdaftar di Bursa Efek Indonesia masih berusaha untuk mementingkan kepentingan pemegang saham sebagai bentuk kepatuhan sebagai 
perusahaan publik. Ketiga, FCF perusahaan lebih banyak dikembalikan lagi kepada pemegang saham dalam bentuk dividen daripada digunakan untuk tujuan konsumtif manajemen.

\section{Pengaruh Leverage Terhadap Cost Stickiness}

Variabel leverage memiliki nilai koefisien regresi bernilai positif, yakni 0.010 . Hal ini berarti variabel leverage berpengaruh positif terhadap cost stickiness. Diketahui nilai t hitung dari variabel leverage adalah 2.482 dan nilai Sig. dari variabel leverage adalah $0.013<0,05$, maka disimpulkan leverage berpengaruh positif dan signifikan terhadap cost stickiness. Hal ini berarti H6 ditolak yakni leverage berpengaruh positif dan signifikan terhadap cost stickiness. Hal ini menunjukkan bahwa ketika leverage meningkat sebesar 1 satuan, maka cost stickiness akan meningkat sebesar 0.010. Bisa dikatakan pengaruh leverage searah ketika leverage meningkat maka tingkat cost stickiness akan meningkat. Hasil penelitian ini sesuai dengan hasil penelitian Calleja et al. (2006), Nelmida \& Siregar (2016), dan Yunaz \& Sasongko (2018).

Tingkat leverage perusahaan akan meningkatkan pengawasan manajemen dalam pengelolaan operasi perusahaan. Perusahaan memiliki kewajiban untuk membayar bunga serta pokok utang kepada kreditor. Hal ini mengakibatkan pengawasan kreditor terhadap manajemen akan meningkat. Manajemen diharuskan untuk mengelola perusahaan dengan struktur biaya yang sensitif dan fleksibel terhadap perubahan aktivitas perusahaan (Calleja et al., 2006). Hal ini berarti ketika penjualan menurun, biaya harus dapat diturunkan mengikuti perubahan penjualan.

\section{Pengaruh Size Terhadap Cost Stickiness}

Variabel size memiliki nilai koefisien regresi bernilai positif, yakni 0.001. Hal ini berarti variabel size berpengaruh positif terhadap cost stickiness. Diketahui nilai t hitung dari variabel size adalah 0.297 dan nilai Sig. dari variabel size adalah $0.766>0,05$, maka disimpulkan size berpengaruh positif terhadap cost stickiness, namun tidak signifikan. Hal ini berarti $\mathrm{H} 7$ ditolak yakni size tidak berpengaruh terhadap cost stickiness. Hasil penelitian ini sesuai dengan hasil penelitian Evelyn (2019) yang tidak menemukan adanya pengaruh variabel size terhadap cost stickiness.

Variabel size tidak berpengaruh signifikan terhadap cost stickiness disebabkan karena adanya keputusan manajemen mengenai pengurangan aset ketika penjualan menurun dan penambahan aset ketika penjualan meningkat. Walaupun perusahaan termasuk ukuran kecil ataupun besar, ketika penjualan tidak mengalami perubahan, maka manajemen tidak akan mengambil keputusan mengenai sumber daya yang harus disesuaikan jumlahnya dengan penjualan yang ada sehingga tidak berpengaruh terhadap cost stickiness.

\section{KESIMPULAN DAN SARAN}

\subsection{Kesimpulan} adalah :

Berdasarkan hasil penelitian dan pembahasan, maka kesimpulan dalam penelitian ini

1) Terdapat perilaku cost stickiness pada biaya penjualan, umum, dan administrasi perusahaan manufaktur yang terdaftar di Bursa Efek Indonesia periode 2014-2018.

2) Asset intensity berpengaruh positif dan signifikan terhadap cost stickiness pada perusahaan manufaktur yang terdaftar di Bursa Efek Indonesia Periode 2014-2018.

3) Employee intensity berpengaruh negatif dan signifikan terhadap cost stickiness pada perusahaan manufaktur yang terdaftar di Bursa Efek Indonesia Periode 2014-2018.

4) Equity intensity tidak berpengaruh terhadap cost stickiness pada perusahaan manufaktur yang terdaftar di Bursa Efek Indonesia Periode 2014-2018. 
5) Return on Equity tidak berpengaruh terhadap cost stickiness pada perusahaan manufaktur yang terdaftar di Bursa Efek Indonesia Periode 2014-2018.

6) Free Cash Flow tidak berpengaruh terhadap cost stickiness pada perusahaan manufaktur yang terdaftar di Bursa Efek Indonesia Periode 2014-2018.

7) Leverage berpengaruh positif dan signifikan terhadap cost stickiness pada perusahaan manufaktur yang terdaftar di Bursa Efek Indonesia Periode 2014-2018.

8) Size tidak berpengaruh terhadap cost stickiness pada perusahaan manufaktur yang terdaftar di Bursa Efek Indonesia Periode 2014-2018.

\subsection{Saran}

Bagi peneliti selanjutnya :

1) Data-data yang digunakan dalam penelitian ini hanya mencakup rentang waktu 2014 hingga 2018. Penelitian selanjutnya diharapkan dapat memperpanjang periode data penelitian.

2) Penelitian selanjutnya diharapkan menguji kategori biaya lain yang memiliki potensi cost stickiness untuk dianalisis lebih lanjut dan dilihat perbandingannya dengan kategori biaya yanglain seperti biaya riset dan pengembangan, biaya iklan, biaya direct labor, beban pokok penjualan serta kategori biaya lainnya.

3) Penelitian selanjutnya sebaiknya menguji faktor-faktor lainnya yang berpengaruh terhadap cost stickiness selain dalam penelitian ini seperti faktor pertumbuhan ekonomi.

Bagi perusahaan :

1) Adanya bukti mengenai sifat sticky yang dimiliki oleh biaya penjualan, umum, dan administrasi menunjukkan bahwa sifat sticky tersebut memang wajar terjadi, namun perlu disadari bahwa hal tersebut dapat memicu pemborosan sumber daya. Perusahaan seharusnya mampu menganalisis respon, sensitivitas dan perilaku setiap kategori biaya perusahaan terhadap perubahan aktivitas bisnis agar dapat meminimalisasi kesalahan pengambilan keputusan, sehingga dapat melakukan pengendalian yang baik terhadap jumlah biaya yang harus dikeluarkan.

2) Mengelola sumber daya perusahaan secara optimal baik sehingga adjustment cost yang dikeluarkan perusahaan tidak terlalu besar.

\section{DAFTAR PUSTAKA}

Abu-Serdaneh, J. (2014). The Asymmetrical Behavior of Cost: Evidence from Jordan. International Business Research, 7(8), 113-122. https://doi.org/10.5539/ibr.v7n8p113

Anderson, M. C., Banker, R. D., \& Janakiraman, S. J. (2003). Are Selling , General , and Administrative Costs “ Sticky ”?41(972), 47-63.

Atkinson, A. A., Kaplan, R. S., Matsumura, E. M., \& Young, S. M. (2012). Management Accounting (6th ed.). New Jersey: Pearson.

Balakrishnan, R., \& Gruca, T. S. (2008). Cost stickiness and core competency: A note. Contemporary Accounting Research, 25(4), 993-1006. https://doi.org/10.1506/car.25.4.2

Banker, R. D., Byzalov, D., \& Plehn-Dujowich, J. M. (2010). Sticky Cost Behavior: Theory and Evidence. SSRN Electronic Journal, (215), 1-74. https://doi.org/10.2139/ssrn.1659493

Banker, R. D., \& Chen, L. (2006). Predicting Earnings Using a Model Based on Cost Variability and Cost Stickiness. The Accounting Review, 81, No. 2, 285-307. 
Banker, R. D., Ciftci, M., \& Mashruwala, R. (2008). Managerial Optimism, Prior Period Sales Changes, and Sticky Cost Behavior. SSRN Electronic Journal. https://doi.org/10.2139/ssrn.1599284

Brigham, E. F., \& Houston, J. F. (2006). Dasar-Dasar Manajemen Keuangan. Jakarta: Salemba Empat.

Brüggen, A., \& Zehnder, J. O. (2014). SG\&A cost stickiness and equity-based executive compensation: does empire building matter? Journal of Management Control, 25(3-4), 169-192. https://doi.org/10.1007/s00187-014-0195-5

Bugeja, M., Lu, M., \& Shan, Y. (2015). Cost Stickiness in Australia: Characteristics and Determinants. Australian Accounting Review, 25(3), 248-261. https://doi.org/10.1111/auar.12066

Calleja, K., Steliaros, M., \& Thomas, D. C. (2006). A note on cost stickiness: Some international comparisons. Management Accounting Research, 17(2), 127-140. https://doi.org/10.1016/j.mar.2006.02.001

Chen, C. X., Gores, T., \& Nasev, J. (2013). Managerial Overconfidence and Cost Stickiness. SSRN Electronic Journal. https://doi.org/10.2139/ssrn.2208622

Chen, C. X., Lu, H., \& Sougiannis, T. (2012). The Agency Problem, Corporate Governance, and the Asymmetrical Behavior of Selling, General, and Administrative Costs. Contemporary Accounting Research, 29(1), 252-282. https://doi.org/10.1111/j.1911-3846.2011.01094.x

de Medeiros, O. R., \& Costa, P. D. S. (2005). Cost Stickiness in Brazilian Firms. Ssrn, i, 1-14. https://doi.org/10.2139/ssrn.632365

Eltivia, N., Ekasari, K., Wahyuni, H., \& Isrowiyah, A. (2019). How Adjustment Cost Relate with. 9(December), 319-326. https://doi.org/10.22219/jrak.v9i3.64

Evelyn, E. (2019). Pengaruh Perubahan Penjualan, Asset Intensity, Profitability, Size, Dan Leverage Terhadap Cost Stickiness. Jurnal Muara Ilmu Ekonomi Dan Bisnis, 2(2), 411. https://doi.org/10.24912/jmieb.v2i2.1609

Garrison, R. H., Noreen, E. W., \& Brewer, P. C. (2010). Managerial Accounting. New York: McGraw-Hill.

Ghozali, I. (2012). Aplikasi Analisis Multivariate dengan Program SPSS. Semarang: Badan Penerbit Universitas Diponegoro.

He, D. (Steven), Teruya, J., \& Shimizu, T. (2010). Sticky Selling, General, and Administrative Cost Behavior and Its Changes in japan. Global Journal of Business Research, 4(4), 1-10.

Kama, I, \& Weiss, D. (2010). DO MANAGERS ' DELIBERATE DECISIONS INDUCE STICKY COSTS? Working Paper, No. 6.

Malcom, R. E. (1991). Overhead Control Implications of Activity Costing. Accounting Horizons, 5(4), 69-78.

Maulinda, V. (2019). EFFECT OF CORPORATE SOCIAL RESPONSIBILITY, LEVERAGE, FIRM SIZE AND PROFITABILITY ON FIRM VALUE IN TEXTILE AND GARMENT INDUSTRY SUBSECTOR COMPANIES LISTED IN INDONESIA STOCK EXCHANGE IN 2014-2016. International Journal Of Public Budgeting, Accounting And Finance, 2(2), 1-15. Retrieved from http://ijpbaf.org/index.php/ijpbaf/article/view/164

Nelmida, \& Siregar, S. O. . (2016). Pengaruh Perubahan Penjualan , Capital Intensity Ratio , 
Debt to Asset Ratio, dan Current Ratio terhadap Cost Stickiness dalam Perusahaan di Bursa Efek Indonesia. Jurnal Ekonomi, Manajemen Dan Perbankan, 2(1), 1-10.

Nugroho, P. I., \& Endarwati, W. (2013). Do the Cost Stickiness in The Selling, General and Administrative Costs Occur in Manufacturing Companies in Indonesia? The Indonesian Journal of Accounting Research, III(September 2013), 25-28.

Pamplona, E., Fiirst, C., Silva, T. B. de J., \& Zonatto, V. C. da S. (2016). Sticky costs in cost behavior of the largest companies in Brazil, Chile and Mexico. Contaduría $y$ Administración, 61(4), 682-704. https://doi.org/10.1016/j.cya.2016.06.007

Pichetkun, N. (2012). the Determinants of Sticky Cost Behavior on Political Costs , Agency Costs , and Corporate Governance Perspectives of Technology Thanyaburi the Determinants of Sticky Cost Behavior on Political Costs, Agency Costs, and Corporate Governance Perspectives. Rajamanggala University of Technology Thanyaburi.

Ratnawati, L., \& Nugrahanti, Y. W. (2015). Perilaku Sticky Cost Biaya Penjualan, Biaya Administrasi Dan Umum Serta Harga Pokok Penjualan Pada Perusahaan Manufaktur. Jurnal Ekonomi Dan Bisnis, XVIII(2), 65-80.

Seay, S. S., Pitts, S. T., \& Kamery, R. H. (2004). THE CONTRIBUTION OF FIRM-SPECIFIC FACTORS: THEORY DEVELOPMENT OF THE RATIO ADJUSTMENT PROCESS. Academy of Strategic Management Journal, 8(1), i-ii.

Sitompul, R. (2020). THE EFFECT OF LIQUIDITY, SOLVABILITY, PROFITABILITY, AND NON PERFORMING FINANCING ON FIRM VALUE WITH INTELLECTUAL CAPITAL AS MODERATING VARIABLES IN MULTIFINANCE COMPANIES LISTED ON INDONESIA STOCK EXCHANGE IN 2015-2018. International Journal of Public Budgeting, Accounting And Finance, 3(1), 153-166. Retrieved from http://ijpbaf.org/index.php/ijpbaf/article/view/241

Situmeang, C. (2014). Manajemen Keuangan. Medan: Unimed Press.

Subramaniam, C., \& Weidenmier, M. L. (2003). Additional evidence on the sticky behavior of costs. Additional Evidence on the Sticky Behavior of Costs, 26, 275-305. https://doi.org/10.1108/S1474-787120150000026006

Wahyuningtyas, Y., \& Nugrahanti, Y. W. (2014). Pengaruh Asset Intensity Dan Employee Intensity Terhadap Sticky Cost Pada Biaya Penjualan, Administrasi, dan Umum. Jurnal Ekonomi Dan Bisnis, 8(2), 113-121.

Warganegara, D. L., \& Tamara, D. (2014). The Impacts of Cost Stickiness on the Profitability of Indonesian Firms. International Journal of Social, Behavioral, Educational, Economic, Business and Industrial Engineering, 8(11), 3606-3609.

Weiss, D. (2010). Cost behavior and analysts' earnings forecasts. Accounting Review, 85(4), 1441-1471. https://doi.org/10.2308/accr.2010.85.4.1441

Windyastuti. (2013). Penetapan Target Terhadap Stickiness Cost. Jurnal Keuangan Dan Perbankan, 17(1), 71-77.

Xue, S., \& Hong, Y. (2016). Earnings management, corporate governance and expense stickiness. China Journal of Accounting Research, 9(1), 41-58. https://doi.org/10.1016/j.cjar.2015.02.001

Yosvid, Y. (2020). THE INFLUENCE OF OPERATIONAL INCOME AND LOAD ASSOCIATION, LEVERAGE, AND FIRM SIZE ON EARNING 
MANAGEMENT. International Journal Of Public Budgeting, Accounting And Finance, 3(1), 178-190. Retrieved from http://ijpbaf.org/index.php/ijpbaf/article/view/243

Yunaz, F., \& Sasongko, C. (2018). Analysis of behavior and determinants of cost stickiness in manufacturing companies in Indonesia. Competition and Cooperation in Economics and Business, 9-17. https://doi.org/10.1201/9781315225227-2

Zanella, F., Oyelere, P., \& Hossain, S. (2015). Are costs really sticky? Evidence from publicly listed companies in the UAE. Applied Economics, 47(60), 6519-6528. https://doi.org/10.1080/00036846.2015.1080807 